\title{
Layanan Referensi Virtual sebagai Strategi Pelayanan di Masa Pandemi Covid-19
}

\author{
Susilowati ${ }^{1}$ \\ ${ }^{1}$ UPT Perpustakaan Institut Seni Indonesia Yogyakarta \\ Jalan Parangtritis km. 6,5 Yogyakarta \\ HP.: 087739708049; Email: susilowati.isiyogyakarta@gmail.com
}

\begin{abstract}
Abstrak
Pandemi covid-19 datang secara tiba-tiba dan telah merubah semua sisi kehidupan, kebijakan dan pembatasan yang diterapkan diberbagai negara menjadikan manusia mengurangi interaksinya dengan manusia lain, hal tersebut dilakukan untuk memutus rantai penularan virus covid-19. Kebijakan pemerintah Indonesia meniadakan pembelajaran tatap muka baik tingkat universitas maupun sekolahsekolah dan menggantinya dengan pembelajaran online/daring membuat penurunan kunjungan dan pemanfaatan perpustakaan oleh pemustaka. Dengan kenyataan tersebut diperlukan sebuah strategi agar perpustakaan khususnya perpustakaan perguruan tinggi tetap bisa berperan sebagai jantung perguruan tinggi. Salah satu strategi layanan yang bisa dilakukan perpustakaan dimasa pandemi ini adalah dengan cara menyediakan layanan referensi vitual. Layanan referensi virtual merupakan salah satu strategi perpustakaan peguruan tinggi dengan menyediakan layanan referensi secara online sehingga layanan tersebut tetap bisa diakses dimanapun berada tanpa harus datang langsung ke perpustakaan. Layanan ini juga sebagai wujud nyata peran serta perpustakaan perguruan tinggi dalam menerapkan social distancing dan mencegah perpustakaan sebagi klaster penularan baru.
\end{abstract}

Kata kunci: pandemi covid-19; layanan perpustakaan; referensi virtual

\begin{abstract}
Virtual Refer Service as a Service Strategy in the Covid-19 Pandemic. Pandemic covid-19 came suddenly, has changed all sides of life, policies and restrictions applied in various countries make humans reduce their interaction with other humans, it is done to break the chain of transmission of the covid-19 virus. The wisdom of the Indonesian government to eliminate face-to-face learning at both the university and school levels and replace it with online learning makes a decrease in visits and utilization of libraries by the library. With this fact, a strategy is needed so that libraries, especially college libraries, can still act as the heart of the college. One of the service strategies that libraries can do in this pandemic period is to provide virtual reference services. Virtual reference services are one of the strategies of high learning libraries by providing online reference services so that they can still be accessed anywhere in the world.
\end{abstract}

Keywords: covid-19 pandemic; library services; virtual reference

\section{A. Pendahuluan}

Pandemi Coronavirus Diseases 19 atau covid-19 telah berlangsung satu setengah tahun lebih. Efek pandemi covid-19 ini telah menimbulkan dampak di berbagai segi kehidupan manusia. Berbagai usaha dan cara dengan bermacam-macam kebijakan telah dilakukan oleh negara-negara di dunia untuk memutus rantai penyebaran virus covid-19. Kebijakan tersebut diantaranya berupa penggunaan masker, kewajiban untuk sering mencuci tangan atau handsanitizer, 
larangan untuk berkerumun dan physical distancing serta dengan berbagai pola karantina sosial baik berskala kecil maupun besar besar, karantina wilayah serta lockdown. Dampak dari kebijakan yang diambil pemerintah tersebut membuat perubahan yang cukup besar bagi kehidupan manusia, diantaranya dalam bidang pendidikan mulai dari Pendidikan sekolah untuk usia dini sampai pendidikan di perguruan tinggi. Kegiatan pembelajaran tatap muka dan kegiatan belajar pengajar menjadi pembelajaran secara onlinel daring. Dalam kegiatan pemerintahan dan layanan di instansi pemerintah dijalankan kebijakan work from home serta layanan terbatas, begitu juga di instansi swasta banyak yang membuat kebijakan yang hampir sama dengan instansi pemerintahan. Di sektor ekonomi banyak perusahaan dan pabrik yang mengurangi karyawannya bahkan ada yang menutup kegiatannya, kegiatan bisnis seperti mall dan supermarket sempat terjadi penutupan dan jika masih buka dengan berbagai protokol kesehatan yang ketat. Pada sektor pariwisata juga sempat mengalami lumpuh total akibat penutupan tempat wisata dan tempat hiburan, dan masih banyak lagi yang diakibatkan oleh pandemi ini.

Terkait dengan adanya wabah atau pandemi tersebut. Kementerian Kesehatan (Kemenkes) telah menerbitkan protokol normal baru (new normal) bagi perkantoran dan industri. Hal tersebut diatur dalam Keputusan Menteri Kesehatan Nomor HK.01.07/MENKES/328/2020 tentang Panduan Pencegahan dan Pengendalian Covid-19 di Tempat Kerja Perkantoran dan Industri dalam Mendukung Keberlangsungan Usaha pada Situasi Pandemi. (Hartono, 2021), Efek pandemi covid-19 di bidang pendidikan mulai dari tingkat sekolah sampai dengan perguruan tinggi sesuai dengan peraturan pemerintah maka ada kebijakan menganti pembelajaran tatap muka menjadi pembelajaran secara onlineldaring. Hal merupakan kegiatan pembelajaran yang baru bagi sebagian besar pelajar dan mahasiswa dan efektivitas pelaksanaannya belum dapat diketahui secara pasti. Hal ini membutuhkan kajian lebih mendalam karena pembelajaran secara onlineldaring belum banyak dilaksanakan oleh berbagai lembaga pendidikan sebelum adanya pandemik covid-19. Pembelajaran onlineldaring yang dilaksanakan oleh berbagai lembaga pendidikan ini dilaksanakan sesuai dengan kemampuan manajemen dan SDM yang ada di masing-masing lembaga pendidikan. Adanya kemampuan dan kesiapan yang berbeda antara satu lembaga pendidikan dan lembaga pendidikan lainnya membuat efektivitas pendidikan dan pembelajaran di berbagai lembaga pendidikan juga bervariatif baik cara dan hasil yang didapatkannya. Lembaga pendidikan harus mampu menghadirkan berbagai alternatif proses pembelajaran bagi siswa dan mahasiswa yang tidak bisa melaksanakan proses pendidikan secara tatap muka. Untuk mendukung pembelajaran ini dibutuhkan SDM dan sarana pendidikan yang memadai. Kenyamanan ruang dan kelengkapan koleksi serta pelayanan yang diberikan oleh perpustakaan adalah syarat mutlak untuk meningkatkan kemauan dan kemampuan belajar mahasiswa yang akan mempengaruhi minat belajar dan berdampak terhadap prestasi belajarnya (Wahyuntini \& Endarti, 2021). Perpustakaan sebagai jantung perguruan tinggi harus mengambil kebijakan koleksi dan layanan baru guna mendukung pelaksanaan pembelajaran onlinel daring lembaga induknya. Perpustakaan harus dapat tetap mendekatkan diri dengan pemustakanya melalui layanan online, sebab perpustakaan tidak boleh "tutup" layanan informasinya, meskipun membatasi bahkan meniadakan layanan tatap muka bagi pemustaka tapi layanan informasi harus tetap berjalan. Meskipun pandemi ini datang secara tiba-tiba tanpa adanya persiapan khusus, akan tetapi pustakawan perpustakaan dan pustakawan dituntut untuk dapat menghadapi kondisi ini sebagai sebuah tantangan baru untuk mampu berinovasi dalam memberikan layananya. Salah satu strategi dan inovasi yang bisa diambil adalah penyediaan layanan referensi online bagi pemustaka. Layanan ini betujuan agar perpustakaan tetap menjadi rujukan pencarian dan temu kembali informasi yang terpercaya dan tidak menjadi klaster penularan baru. Kesehatan pustakawan dan pemustaka merupakan prioritas utama dalam mengambil setiap kebijakan dalam memberikan layanan perpustakaan. Meskipun pandemi ini datang secara tiba-tiba tanpa adanya persiapan pustakawan untuk menghadapinya tapi pustakawan 
harus mampu berinovasi dalam memberikan layananya, salah satu strategi dan inovasi yang bisa diambil adalah penyediaan layanan referensi online bagi pemustaka. Dalam memberikan layanan referensi online ini perpustakaan harus memperhatikan beberapa faktor melalui analisis kekuatan, kelemahan, kesempatan, dan ancaman yang ada. Dalam tulisan ini akan dibahas mengenai layanan referensi online di perpustakaan dan faktorfaktor yang mempengaruhinya.

\section{B. Hasil dan Pembahasan}

Kata referensi berasal dari bahasa Inggris "reference" yang berarti menunjuk kepada, atau menyebut. Menurut William A. Katz (1987) fokus dari layanan referensi adalah pada pemberian jawaban atas pertanyaan referensi atau pencarian informasi. Sedangkan dalam Buku Pedoman Perpustakaan Perguruan Tinggi (Departemen Pendidikan dan Kebudayaan Dirjen Dikti, 1994: 45) Pelayanan referensi adalah bagian perpustakaan yang kegiatannya membantu pemustaka menelusur referensi dalam berbagai subyek. Dengan pelayanan ini pemakai dibantu menemukan informasi dengan cepat, menelusur informasi dengan lebih spesifik dan memanfaatkan sarana penelusuran yang tersedia secara optimal. Dari beberapa pengertian layanan referensi di atas dapat diambil kesimpulan bahwa layanan referensi diartikan sebagai layanan yang diberikan pustakawan dalam membantu pemustaka mengindentifikasi sumber informasi dan menjawab pertanyaan pemustaka tentang masalah tertentu dengan memanfaatkan koleksi referensi yang ada.

Layanan referensi mempunyai beberapa fungsi yaitu fungsi informasi. Dengan adanya layanan referensi diharapkan pustakawan mampu memberikan informasi yang dibutuhkan pemustaka dan menjawab pertanyaan-pertanyaan pemustaka dengan cara memanfaatkan koleksi referensi yang ada di perpustakaan. Layanan referensi mempunyai fungsi bimbingan. Pustakawan di bagian layanan referensi memberikan bimbingan kepada pemustaka untuk menemukan bahan pustaka yang dibutuhkannya dan memberikan bimbingan bagaimana cara memanfaatkan bahan-bahan pustaka referensi tersebut. Layanan referensi mempunyai fungsi pengarahan dan instruksi. Pustakawan memberikan intruksi kepada pemustaka bagaimana cara memanfaatkan koleksikoleksi referensi yang ada diperpustakaan. Hal ini bertujuan untuk mengenalkan dan meningkatkan penggunakaan koleksi-koleksi referensi yang ada diperpustakaan. Layanan referensi mempunyai fungsi supervisi, pustakawan mengamati pemustaka koleksi referensi baik dalam kebutuhan informasi maupun latar belakang social dan pendidikanya sehingga pustakawan mampu memberikan informasi sesuai dengan latar belakang sosial serta tujuan pemustaka berkunjung ke layanan referensi. Layanan referensi mempunyai fungsi bibliografi, pustakawan di layanan referensi biasanya akan menyusun bibliografi untuk kepentingan penelitian maupun mengenalkan bacaan yang menarik untuk pemustaka. Pada perpustakaan perguruan tinggi penyusunan bibliografi biasanya bertujuan untuk kepentingan penelitian dan karya tulis civitas akademiknya.

Dalam layanan referensi tidak bisa dilepaskan dengan koleksi referensi. Koleksi referensi adalah kumpulan bahan pustaka jenis sekunder dan tersier yang biasannya ditempatkan secara khusus dibagian rujukan, yang terdiri atas bahan pustaka yang diolah sebagai sumber informasi khusus dan tidak untuk dibaca secara keseluruhan, dan bersifat menunjukan kepada informasi tertentu untuk kepentingan konsultasi pemakai. Ada beberapa pengelompokan bahan referensi yaitu berdasarkan: a. Bahan referensi yang berisi informasi mengenai kata dan istilah. Contoh bahan referensi yang berisi kata atau istilah adalah:

1. Kamus

Kamus merupakan bahan referensi yang berisi tentang daftar kata dasar dari suatu bahasa yang disusun menurut abjad. Sedangkan kamus dapat dikelompokan lagi berdasarkan isinya yaitu kamus umum (kamus umum ini berisi tentang daftar kosa kata secara umum dengan segala keteranganya), kamus khusus (kamus yang menjelaskan salah satu aspek dari kosa kata yang didaftar), kamus subjek ( kamus ini mengkhususkan diri dengan berisikan salah satu subjek saja). 
Pengelompokan kamus berdasarkan jumlah bahasanya yaitu kamus ekabahasa (kamus ini disusun hanya menggunakan satu bahasa saja, disusun secara alfabetis dengan penjelasan makna dan contoh pemakaiannya di dalam sebuah kalimat bahasa yg sama), kamus dwibahasa (kamus ini disusun secara alfabetis menggunakan dua bahasa dalam kamus ini juga diberikan contoh pemakaianya dalam dua bahasa), kamus aneka bahasa (kamus ini disusun secara alfabetis menggunakan lebih dari dua bahasa). Pengelompokan kamus berdasarkan jumlah kandungan entrinya dapat dibedakan kedalam kamus singkat, kamus sedang, dan kamus lengkap.

\section{Ensiklopedi}

Ensiklopedi merupakan bahan referensi yang menyajikan informasi secara mendasar namun lengkap mengenai berbagai ilmu pengetahuan. Lazimnya ensiklopedi disusun berdasarkan abjad. Kemutahiran ensiklopedi dijaga oleh penerbitnya dengan cara menerbitkan edisi terbaru. Ensiklopedi dapat dibagi menjadi beberapa yaitu ensiklopedi nasional/umum (ensiklopedi ini dibuat untuk dipasarkan dinegara tertentu, karena ensiklopedi ini memuat informasi negara yang bersangkutan), ensikopedi khusus/ ensiklopedi subjek (ensiklopedi ini memuat subjek atau bidang tertentu atau menekankan pada bidang tertentu), ensiklopedi universal/ internasional (ensiklopedi ini memuat informasi dari berbagai Negara atau dikebanyakan diseluruh dunia).

b. Bahan informasi yang berisikan tentang sumber kepustakaan (literature).

Bahan pustaka referensi ini adalah jenis bahan pustaka yang memuat mengenai sumber kepustakaan (literatur), adapun jenisnya ada beberapa yakni katalog (daftar yang berisi informasi tentang bahan pustaka atau dokumen yang ada dalam suatu tempat. Index (dibuat untuk menunjukan dimana dan kemana informasi itu bisa ditemukan), bibliografi (buku yang disusun berdasarkan abjad dan memuat daftar terbitan baik buku maupun majalah atau sumber kepustakaan lain), abstrak (disebut juga dengan ringkasan, dalam pembuatanya tanpa ditambahan atau kritik dari abstraktor), paket infomasi kilat atau paket daftar daftar isi majalah (berisi tentang kumpulan daftar isi majalah yang dijilid khusus dan menjadi buku tersendiri).

c. Bahan rujukan lainnya.

Bahan-bahan koleksi referensi yang termasuk dalam bahan rujukan lainya diantaranya buku pedoman atau buku pegangan, bahan pustaka sumer bibliografi, bahan pustaka sumber geografi, direktori, statistik, buku tahunan, terbitan pemerintah dll.

Pada masa pandemi covid-19 ini di dalam perpustakaan perguruan tinggi juga melakukan banyak pembatasan dalam jenis layanan maupun jam layananya. Pembatasan ini dilakukan semata-mata guna memprioritaskan kesehatan pustakawan pemustakanya. Walaupun pembatasan diterapkan diperpustakaan tetapi layanan informasi perpustakaan tidak boleh "tutup" dan diperlukan strategi baru agar tetap berjalan tanpa adanya kontak fisik pustakawan dengan pemustaka. Pemustaka tidak perlu berkunjung keperpustakaan secara fisik. Salah satu strategi yang dilakukan yaitu dengan cara melaksanakan layanan referensi virtual. Layanan ini sebagai pengembangan salah satu jenis layanan referensi guna menjawab permasalahan baru yang ada di masyarakat pemakainya. Layanan layanan referensi virtual sebenarnya bukan hal baru di perpustakaan, akan tetapi pemanfaatannya secara maksimal sangat terasa pada masa pandemic covid-19 ini. Layanan referensi virtual memfokuskan diri pada jaringan internet sebagai sarana penghubung antara pustakawan dan pemustaka, layanan ini juga sebagai wujud nyata perpustakaan mengambil peran aktif dalam memutus rantai penyebaran virus covid-19 dengan melayani kebutuhan pemustakanya melalui layanan referensi virtual. Pada awalnya layanan memiliki tujuan untuk melayani para pemustaka yang bertempat tinggal jauh dari perpustakaan tetapi tetap ingin mengakses informasi yang ada diperpustakaan. Pada masa pandemi covid-19 saat ini layanan tersebut tepat untuk diterapkan diperpustakaan guna menerapkan social distancing. Menurut Kismiyati, Titiek (Kismiyati, 2020) layanan virtual diterapkan 
di perpustakaan yang berada di zona oranye dan merah, di mana risiko penularan covid-19 tinggi. Perpustakaan harus menggunakan media yang memungkinkan pemustaka memanfaatkan layanan perpustakaan tanpa harus datang ke perpustakaan, bekerja sama dengan perpustakaan lain karena tidak mungkin suatu perpustakaan memiliki semua koleksi yang dibutuhkan, serta lembaga lain dalam hal pengiriman koleksi. Oleh karena itu, perpustakaan selain meningkatkan kompetensi pustakawan, juga harus memperkuat layanan digital, yaitu dalam hal penyediaan koleksi, layanan sirkulasi, referensi, dan penyelenggaraan kegiatan secara online. Arya (2003:103) menyatakan bahwa: Many Terms are used to express the study and practice of digital reference, for example digital reference, virtual reference, real-time reference, chat reference, real-time chat reference, live reference Ask a Librarian, Ask Us, Ask On, Ask Away are used interchangeably as terms with similar meaning.

Dari pendapat di atas layanan referensi virtual yang diberikan pustakawan dapat berupa:

\section{a. Ask a Librarian}

Layanan ini memungkinkan pemustaka menggunakan saluran live chat dan pesan teks nya untuk meminta bantuan pustakawan dalam mendapatkan informasi yang mereka inginkan. b. Ask Us

Layanan ini digunakan khusus untuk menjawab pertanyaan-pertanyaan yang berasal dari para pelajar.

c. Ask On

Layanan ini merupakan layanan untuk membantu menjawab pertanyaan-pertanyaan dari pemustaka dan penunjukkan pada pemustaka dimperpustakaan mana informasi tersebut berada.

\section{d. Ask Away}

Layanan ini bertujuan untuk menjawab pertanyaan yang berhubungan dengan penelitian dengan memanfaatkan sumber daya informasi yang miliki perpustakaan.

Layanan referensi virtual di atas dapat dilaksanakan dengan memanfaatkan email, web serta kontak person yang ada diperpustakaan. Semua pertanyaan pemustaka akan dijawab oleh pustakawan dengan cara memanfaatkan koleksi yang ada diperpustakaan. Menurut Arya (Arya \& Mishra., 2012: 104)layanan referensi virtual mempunyai beragam fungsi diantaranya, menyediakan layanan informasi perpustakaan bagi pengguna terpencil, mengembangkan dukungan perpustakaan bagi penelitian dan pendidikan, membantu mengembangkan dan memelihara sumber koleksi virtual reference, memperkenalkan pengguna potensial kepada pengguna biasa, menyediakan bantuan kepada pengguna tentang pencarian yang baik, lengkap dan sumber informasi yang valid, membantu para pengguna dalam penelusuran online, menghemat waktu para pengguna, menyediakan layanan dari setiap kota yang berbeda sehingga layanan virtual reference hadir sebagai agen hubungan masyarakat, menyediakan kepada pengguna yang mengarah kepada para pengguna terpencil, menanamkan dan menguatkan hubungan dengan para pengguna, mengembangkan promosi dan penyampaian sumber perpustakaan dan pelayanannya, memungkinkan pencapaian dari tujuan organisasi, memungkinkan mencukupi lima hukum dari ilmu perpustakaan. Fungsi layanan referensi virtual yang dikemukakan di atas merupakan fungsi secara umum sebelum pandemi covid-19 berlangsung, setelah adanya pandemi covid-19 fungsi layanan referensi virtual sebagai bentuk nyata perpustakaan dalam menerapkan social distancing dan sebagai upaya memutus rantai penularan covid-19.

Untuk melaksanakan layanan referensi virtual dibutuhkan beberapa persiapan. Hal yang pertama kali harus dilakukan adalah dengan analisis kekuatan, kelemahan, kesempatan, ancaman yang dikenal dengan istilah analisis SWOT (Streng, Weakness, Opportunity, Threat). Analisis ini digunakan untuk menganalisa permasalahan, mengenali potensi yang dimiliki oleh perpustakaan dan juga digunakan untuk menentukan kebijakan, pengambilan keputusan, pengembangan perpustakaan di masa datang. Analisis SWOT (Streng, Weakness, Opportunity, Threat) terdiri dari faktor internal (dalam) perpustakaan dan faktor eksternal (luar) perpustakaan, faktor internal meliputi strength (kekuatan) dan weakness (kelemahan) serta faktor eksternal yang terdiri dari Opportunities (kesempatan) dan threats (ancaman). 
Faktor eksternal perpustakaan yang me-rupakan strength (kekuatan) terdiri dari koleksi perpustakaan, sumber daya manusia (baik pustakawan maupun non pustakawan), sarana dan prasarana. Faktor weaknes/kelemahan yang ada di perpustakaan terdiri dari koleksi, sumber daya manusia, sarana prasarana yang kurang memadai guna mendukung layanan referensi virtual. Sedangkan faktor eksternal perpustakaan yang menjadi opportunity/kesempatan terdiri dari pemustaka yang potensial, kebutuhan informasi masyarakat, perkembangan teknologi informasi, jaringan kerjasama dan resource sharing antar pepustakaan, website yang menyediakan beragam informasi, tersedianya internet yang memadai, dan dukungan dari lembaga induk. Faktor eksternal perpustakaan yang membuat treats /ancaman adalah kompetensi yang sangat ketat menuntut kualitas sumber daya manusia, perubahan perilaku pemustaka akan kebutuhan informasi, virtual library, virus komputer yang menyerang software layanan perpustakaan, perbedaan persepsi tentang policy open content informasi pada digital library. Analisis SWOT bisa dilakukan oleh pustakawan dengan dukungan tenaga ahli dari lembaga induknya. Dengan melakukan analisis SWOT maka akan diketahui apa saja yang menjadi sumber daya, keterbatasan yang bisa menghambat, peluang apa saja yang memberi dukungan serta hal apa saja yang bisa menjadi ancaman dalam pelaksanaan layanan referensi virtual.

Pelaksanaan layanan referensi virtual perlu memperhatikan pedoman agar dapat berjalan dengan lancar. Reference and User Services Association (RUSA) merupakan salah satu komite dalam American Library Association (ALA) yang khusus menangani layanan referensi memberikan pedoman hal-hal yang perlu diperhatikan dalam mengimplementasikan layanan referensi virtual (IFLA: 2002), yaitu:

1. Persiapan (integrasi dengan layanan yang lama, komitmen institusi, tim khusus, pemilihan perangkat lunak, pengembangan koleksi, dan penilaian sistem),

2. Perbekalan (target dan parameter layanan, sumber daya manusia, perilaku layanan, dan kemungkinan kerja sama antar perpustakaan),

3. Pengorganisasian (integrasi layanan referensi virtual, infrastruktur, keuangan, pemasaran, dan evaluasi untuk perbaikan), dan privasi.

Pustakawan sebagai sumber daya manusia layanan referensi menurut Reference and User Services Association memberikan pedoman perilaku kerja (RUSA: 2010) sebagai berikut:

1. Pustakawan referensi virtual harus memiliki keterampilan komunikasi dan interpersonal serta bersedia membantu pemustaka dalama memenuhi kebutuhan informasinya. Mempunyai keterampilan tambahan, atau pelatihan untuk memberikan layanan berkualitas setara dengan layanan referensi tatap muka.

2. Mempertahankan pedoman standar layanan referensi (seperti wawancara referensi, pertukaran pertanyaan antara layanan, dll.)

3. Mempraktekkan komunikasi interpersonal yang mempromosikan penyediaan layanan referensi yang efektif sebagaimana diartikulasikan dalam RUSA "Pedoman Kinerja Perilaku Profesional Referensi dan Layanan Informasi."

4. Pustakawan harus memiliki keterampilan dalam penggunaan komunikasi online yang efektif, dan menunjukkan kemampuan untik memahami permasalahan saat melakukan wawancara referensi secara online dibandingkan dengan wawancara referensi tatap muka

5. Menawarkan pelatihan untuk membantu staf mempelajari dan mempertahankan perilaku online yang efektif.

6. Perlakukan komunikasi online pelanggan dan kolega, termasuk transkrip atau catatan yang disimpan, sebagai hal pribadi dan rahasia.

Dengan menerapkan analisa SWOT dan pedoman-pedoman yang dikeluarkan oleh RUSA diharapkan mampu mewujudkan layanan referensi virtual yang handal. Dukungan dari lembaga induk juga sangat mempengaruhi keberadaan dan kelangsungan layanan ini. Kerjasama dengan para ahli dibidang lain atau unit lain di dalam lembaga pendidikan dengan melakukan kolaborasi juga diperlukan guna kelancaran layanan referensi virtual.

\section{Kesimpulan dan Saran}

Pandemi covid-19 yang belum diketahui kapan berakhirnya menjadi tantangan dan 
kesempatan tersendiri bagi perpustakaan dan pustakawan dalam mendukung lembaga induknya melaksanakan proses belajar mengajar secara onlinel daring. Perpustakaan harus tetap hadir menjadi sumber informasi referensi virtual terpercaya serta terus melakukan inovasi dan strategi baru sehingga memungkinkan pemustaka memanfaatkan layanan perpustakaan tanpa harus datang ke perpustakaan. Analisis SWOT sangat diperlukan untuk mengetahui apa saja yang menjadi sumber daya, keterbatasan yang bisa menghambat, peluang apa saja yang memberi dukungan serta hal apa saja yang bisa menjadi ancaman dalam pelaksanaan layanan referensi virtual. Pandemi covid-19 diharapkan bukan lagi menjadi penghalang untuk tetap memberikan layanan prima perpustakaan dan memenuhi kebutuhan akan informasi yang dibutuhkan para pemustakanya. Kesiapan SDM dan sarana prasarana pendukungnya sangat diperlukan dalam melaksanakan layanan ini. Dengan memanfaatkan fasilitas ask a librarian, ask us, ask on, ask away maka pemustaka dapat memperoleh informasi yang ada diperpustakaan secara online tanpa harus datang ke perpustakaan.

\section{Kepustakaan}

Arya, H. B., \& Mishra., J. K. (2012). Virtual Reference Service: Tools and Techniques. Journal of Library \& Information Science, 2(1), 102-116.

Departemen Pendidikan dan Kebudayaan Dirjen
Dikti. (1994). "Perpustakaan Perguruan Tinggi": Buku Pedoman. Dirjen Dikti.

Hartono, A. (2021). Pemustaka di Perpustakaan Program Pascasarjana ISI Yogyakarta Setelah Penerapan Protokol Kesehatan Covid-19. Abdi Pustaka, 1(1), 25-31. https://doi. org/10.24821/jap.v1i1.5912

Kismiyati, T. (2020). Makalah dipresentasikan dalam webinar 25 Tahun Hari Kunjung Perpustakaan dan Bulan Gemar Membaca. Prinsip Layanan Perpustakaan Dimasa Pandemi. 15 September. Jakarta.

Wahyuntini, S., \& Endarti, S. (2021). Tantangan Digital dan Dinamisasi Koleksi dalam Pemanfaatan Koleksi Perpustakaan bagi Prestasi Belajar Mahasiswa. Abdi Pustaka, 1(1), 1-6.

\section{Webtografi}

International Federation of Library Associations and Institutions. (2002). IFLA Digital Reference Guidelines. 4 September 2017. https://www. ifla.org/wp-content/uploads/2019/05/ assets/reference-and-information-services/ publications/ifla-digital-reference-guidelinesen.pdf.

Reference and User Services Association. (2010). Guidelines for implementing and maintaining virtual reference services. 2 Desember 2020. http://www.ala.org/rusa/sites/ala.org.rusa/ files/content/resources/guidelines/virtualreference-se.pdf. 